\title{
Meaning construction in the Brexit process
}

\author{
María Enriqueta Cortés de los Ríos ${ }^{1}$. \\ Universidad de Almería \\ Carrera Sacramento s/n La Cañada de San Urbano 04120 Almería (Spain) \\ Tamara Hernández Aparicio \\ Universidad de Almería
}

https://orcid.org/0000-0003-3871-4036

\section{Abstract}

The aim of this study is to explore how verbal, pictorial and multimodal modes contribute to the communication of the separation process between Britain and the EU, known as Brexit, by means of cognitive tools such as metaphor, metonymy and image schemas. This analysis has been structured according to the Conceptual Metaphor Theory (Lakoff \& Johnson 1980; Charteris-Black \& Musolf, 2003; Charteris-Black, 2004, Ruiz de Mendoza \& Pérez, 2011, among others) and the Theory of Multimodal Discourse (Forceville 1996, 2006, 2009, 2012; Forceville \& Urios-Aparisi, 2009). The data collected for analysis consists of some covers of The Economist magazine, dealing with different stages of the process, published during the 2015-2017 period. The results of the analysis reveal that metaphors and metonymies are usually cued by pictures and also by the interaction of pictures and text. More particularly, pictorial metonymies and verbal-pictorial metaphors are the most recurrent. Finally, image schemas, rendered pictorially, contribute to the creation of negative evaluative meaning in the corpus selected.

Keywords: metaphor, metonymy, image schemas, political discourse, Brexit.

\section{RESUMEN}

El objetivo de este estudio es explorar cómo los modos verbales, pictóricos y multimodales contribuyen a la comunicación del proceso de separación entre Gran Bretaña y la UE, conocido como Brexit, a través de herramientas cognitivas como la metáfora, la metonimia y los esquemas de imagen. Este análisis ha sido estructurado de acuerdo con la Teoría Conceptual de la Metáfora (Lakoff \& Johnson 1980; Charteris-Black \& Musolf, 2003; Charteris-Black, 2004, Ruiz de Mendoza \& Pérez, 2011, entre otros) y la Teoría del Discurso Multimodal (Forceville 1996, 2006, 2009, 2012; Forceville \& Urios-Aparisi, 2009). Los datos recopilados para el análisis lo conforman portadas de la revista The Economist, que tratan sobre diferentes etapas del proceso publicadas durante el período 2015-2017. Los resultados del análisis revelan que las metáforas y las metonimias generalmente se basan en imágenes y también en la interacción de imágenes y texto. Más concretamente, las metonimias pictóricas y las metáforas verbo-pictóricas son las más recurrentes. Finalmente, los esquemas de imágenes se muestran a nivel pictórico y la mayoría de ellos transmiten una evaluación negativa.

Palabras clave: metáfora, metonimia, esquemas de imágenes, discurso político, Brexit.

\section{Introduction}

Brexit, a portmanteau of 'Britain' and 'exit', has been used as a shorthand way of denoting the United Kingdom's (UK) prospective withdrawal from the European Union (EU). In 1973, Britain joined the European Economic Community although it did not fully believe in the idea of a common market and single currency. From the 1990s onwards, a deep discontent regarding the EU's budget regulation and economic affairs started to gain popularity among British citizens. The force of this anti-Europe movement urged David Cameron to hold a 
referendum so that the country could decide: 'Leave or stay'. The plebiscite was held on June $23^{\text {rd }} 2016$ and more than 30 million people voted. After the recount, 51.9\% of votes cast were in favour of leaving while $48.1 \%$ of votes cast were in favour of staying. These results meant that Britain had decided to walk away from the EU. After David Cameron's resignation, Theresa May assumed the leadership of a country whose departure from Europe was unavoidably approaching. On March $29^{\text {th }}$ 2017, May invoked article 50 of the Lisbon Treaty as the official mechanism for exiting the EU. At the time of writing this paper, the UK needed to leave Europe in two years' time (March 2019).

This historic event has a great impact inside and outside Britain's borders. Mass media play an active role throughout the whole process of Brexit. Magazines as a type of print media contain covers which transmit updated information. Magazine front covers tend to combine the verbal and the visual with the intention of attracting, informing and persuading potential readers. Cortés de los Ríos (2010: 84) argues that a "magazine cover is not simply a visual and verbal summary of what is considered the most important current topic; it is also an important form of self-advertising". For that reason, it should be effective and as attractive to readers as possible in order to make them buy the magazine. In this vein, Silaški \& Đurović (2017: 126) argue that "it is possible to speak of the language of magazine front covers as a special type of multimodal discourse". In addition, these authors point out $(2017: 131)$ that "a magazine cover functions metonymically in relation to the whole text contained inside, thus having to be strong and salient enough as a part to represent the whole".

In this paper, we aim to explore how verbal, pictorial and multimodal modes contribute to the communication of the separation process between Britain and the EU by means of cognitive tools such as metaphor, metonymy and image schema. For this purpose, we analyse ten covers of The Economist, the prestigious business and current affairs magazine, which illustrate different stages of Brexit during the 2015-2017 period².

The structure of this paper is as follows: after this brief introduction, in section 2 we will deal with the theoretical framework underlying this study. The third section describes the data collection and methodology. The fourth presents the analysis. The fifth shows the results. Finally, we draw some conclusions.

\section{Theoretical framework}

\subsection{Political discourse in magazine covers}

Political discourse is the use of language to do the business of politics and includes persuasive rhetoric, the use of implied meanings, the use of euphemisms, the exclusion of references to undesirable reality, the use of language to arouse political emotions and the like (Chilton, 2008: 226). A number of researchers have given a theoretical account of metaphor in political discourse. Lakoff \& Johnson (1980) describe metaphors as playing a central role in the construction of social and political reality. They define metaphor as being able to hide aspects of reality and especially significant in the area of politics because metaphors constrain our lives. Furthermore, "political ideologies are framed in metaphorical terms" (Lakoff \& Johnson, 1980: 236). Chilton \& Schäffner (1997: 221) suggest metaphor to be "a crucial conceptual and semantic mechanism in the production of political meaning". Bijeikienė \& Meškauskienė (2013: 92) state that "research on political metaphor takes a more

2 This paper is based on the R\&D Project within the framework of the "Programa Operativo FEDER Andalucía 2014-2020, code B-HUM177UGR18 
interactive or pragmatic perspective. Here, metaphor is viewed as a source of communicative dynamics by regulating the balance between implicitness and explicitness". Kövecses (2010: 68) maintains that "politics in general is rife with conceptual metaphors". Many political issues are complex and abstract for voters to understand them; hence metaphors can serve to help voters comprehend abstract entities through more concrete ones (Mio, 1997). In addition, politicians use metaphors to make persuasive arguments clearly demonstrating their ability of thinking rationally (Burkholder \& Henry, 2009). Furthermore, political journalists tend to use metaphors to make a complex political process more palatable for their audiences (Cammaerts, 2012).

Lakoff (1993) argued that metaphors can function as an ideological weapon due to the fact that they can serve to frame political and socio-economic issues. The choice of metaphors for a magazine cover seems only natural because the combination of visual and verbal elements together helps the reader to easily process information and construct meaning from the reading (Silaški \& Đurović, 2017). For the same reason, the combination of these two elements has a stronger rhetorical effect and much more persuasive power over the reader than words alone. The important role of images in current newspapers, magazines, public relations materials, advertisements and various kinds of books cannot be disregarded. (Kress \& Van Leuween, 2006). Covers set an idea into the minds of readers and manipulates their opinions (Deepali 2016).

\subsection{Conceptual metaphor theory and multimodal discourse}

The theoretical foundations of this study are based on the Conceptual Metaphor Theory (Charteris-Black, 2004; Charteris-Black \& Musolff, 2003; Lakoff \& Johnson, 1980; Ruiz de Mendoza \& Pérez-Hernández, 2011, among others) on the one hand, and the Theory of Multimodal Discourse (Forceville, 1996, 2006, 2009, 2012; Forceville \& Urios-Aparisi, 2009, among others) on the other, in which meaning is created through other modes of communication apart from verbal. Some cognitive and multimodal studies have focused on different fields of ESP such as advertising (Forceville, 2006, 2008, 2012); politics (Negro Alousque, 2015) and economics (Cortés de los Ríos, 2010; Cortés de los Ríos \& Felices-Lago, 2017; Silaški \& Đurović, 2010). Previous research on verbal metaphors in the Brexit discourse has been carried out by researchers like Musolff (2017), Đurović \& Silaški (2018), Koller, Kopf \& Miglbauer (2019), among others.

Conceptual Metaphor Theory (CMT) started with George Lakoff and Mark Johnson's book, Metaphors We Live By (1980). Lakoff \& Johnson (1980: 5) define metaphor as "understanding and experiencing one kind of thing in terms of another". Metaphors follow the pattern A IS B. One of the most common examples is ARGUMENT IS WAR. Thus, we apply what we know about 'war' (the source domain) to 'argument' (the target domain). Not only does this metaphor manifest itself in expressions such as "I've never won an argument with him" or "You disagree? Okay, shoot!" but also in the way we behave and understand what happens when we have an argument. However, since the features of a single source domain only cover one aspect of the target domain, we need different source domains in order to understand the latter fully. Thus, an argument can also be a building, a container, etc.

While rather neglected at the early stages of cognitive linguistic research, metonymy has gradually been recognised as an equally important cognitive device for influencing the way humans think (Barcelona, 2000). Lakoff \& Johnson (1980: 35) initially described "metonymy as a way of using an entity to refer to another that is related to it". 
Metonymy also refers to mappings between conceptual domains, but unlike metaphor, in this particular case, the mapping occurs within a single domain and not across domains. In any metonymic expression there is a "stand for" relationship (Lakoff \& Johnson, 1980) so that one entity in a schema is taken to stand for another entity in the same domain or for the domain as a whole. There are some scholars such as Goossens, (1995) and Ruiz de Mendoza (2000) who claim that there is no clear-cut difference between these two cognitive devices and that they may interact in many ways. The possible interaction patterns that can occur between metaphor and metonymy, traditionally referred to as metaphtonymy, were first described by Goossens who found two cases where interaction between metaphor and metonymy occurred: "One in which the experiential basis for the metaphor is a metonymy, yielding what we call metaphor from metonymy, the other in which the metonymy, functioning in the target domain, is embedded within a metaphor, i.e. metonymy within metaphor"(Goosens, 1995: 174). Later this concept was revised and expanded by Ruiz de Mendoza (2000), Ruiz de Mendoza \& Díez Velasco (2002) and Ruiz de Mendoza \& Galera Masegosa (2014) who affirm that there are other ways in which metaphor and metonymy interact. Basically, metonymy is subsidiary to - and thus part of - metaphor. There are two basic metonymic schemas: part-for-whole (source-in-target) and whole-for-part (target-in-source). Metonymic expansions (source-in-target) and reductions (target-in-source) can occur either in the source or the target domain of the metaphoric mapping or in one of their correspondences. García Castillo (2004: 7) illustrates both schemas. An example of the source-in-target metonymy would be: "We need more hands in the farm, where hands refers to the workers, thus hands appears as a subdomain of the wider domain workers. Conversely, in the second type of metonymy (target-in-source-metonymy) the target domain is a subdomain of the source domain. She is learning to tie her shoes is an example of this type; here the concept shoes refers to laces (laces is a subdomain of shoes)".

According to Multimodal Discourse a number of researchers have given a theoretical account of pictorial and multimodal cognitive tools (Forceville, 1996, 2008, 2012; Kress \& van Leeuwen, 2001; Ventola, Cassily, \& Kaltenbacher, 2004). Some of them have studied the use of these tools in specialised language such as wine speak (Caballero \& Suárez-Toste, 2008), advertising (Forceville, 1996, 2008) and film (Forceville, 2016).

As for metaphor, Forceville (2006) argued that:

(...) if conceptual metaphor theory is right in assuming that humans pervasively use verbal metaphor because they largely think metaphorically, then metaphorical thought should manifest itself not just in language, but also via all other modes of communication, such as pictures, music, sounds and gestures. (Forceville, 2006: 10)

Consequently, according to Forceville (2006: 383) "metaphors can occur in other modes, not only language. By mode, he refers to a sign system that can be interpretable due to a specific perception process". He agrees with Johnson's idea (1987: 209) that "meaning is not only restricted to words but there is also embodied meaning in the field of arts that can be comparable to linguistic meaning. Therefore, metaphorical thought can be expressed in different modes of communication other than just verbal".

Forceville (2006) identified different metaphorical realizations commonly found in the field of advertising and he has established three different categories of metaphor. These are verbal, pictorial and multimodal metaphors. Pictorial and multimodal metaphors have been far less studied than their verbal counterpart but according to Forceville (2006: 3), "these two categories are essential to fully comprehend why metaphors may be expressed by language but they are not necessarily linguistic in nature". For a combination of two phenomena to be construable as a multimodal metaphor, three criteria must be met: 
The two phenomena belong to different categories. The two phenomena can be captured in an A IS B format that invites the addressee to map one or more features or connotations from source to target and the two phenomena are cued in more than one sign system, sensory mode, or both. As a result, when the target and source domain are rendered in two different sign systems (visual, written, spoken), or modes of perception (smell, taste, and touch), even if the 'A is B' format is maintained, we obtain a multimodal metaphor. (Forceville, 2008: 469)

The relationship of metaphor and metonymy in the construction of meaning can be appreciated in multimodal contexts (Cortés de los Ríos, 2010; Pérez Sobrino, 2017; Silaški \& Đurović, 2017).

\subsection{Image schemas}

Although image schemas have initially received less attention than metaphors and metonymies, they also play an important role in understanding and structuring concepts. Cognitive literature has revealed that image schemas provide the basis for a large number of metaphoric and metonymic mappings (Johnson, 1987; Lakoff, 1987; Lakoff \& Johnson, 1980, 1999; Lakoff \& Turner, 1989) and underlie metaphor-metonymy interaction (Díez Velasco, 2001; Ruiz de Mendoza, 1997). The first author that addressed image schemas was Johnson (1987: xiv, xvi), who described them as follows:

\footnotetext{
"a recurring dynamic pattern of our perceptual interactions and motor programs that gives coherence and structure to our experience [...] "Experience" [...] is it to be understood in a very rich, broad sense as including basic perceptual, motor-program, emotional, historical, social and linguistic dimensions".
}

Evans \& Greens (2006: 176) also contributed to the development of this device and offered their own definition. They considered image schemas as "relatively abstract conceptual representations that arise directly from our everyday interaction with and observation of the world around us". This means that we are not born with this knowledge, although it is acquired during our early childhood, which is the reason why we are not even aware of it. For example, the fact that we have a head at the top of our body and feet at the bottom, that we walk upright, and gravity exists, determines the way we interact with our environment. Given all these conditions, if we want to pick up an object from the floor, we have to stop and bend down. From this experience we infer the schema UP-DOWN, but there are plenty more.

We adopt Evans \& Green's list of image schemas (2006: 190) for the purposes of our study:

Space: UP-DOWN, FRONT-BACK, LEFT-RIGHT, NEAR-FAR, CENTRE-PERIPHERY, PATH, STRAIGHT-CURVED, SCALE.

Containment: IN-OUT, FULL-EMPTY.

Multiplicity: PART-WHOLE, COUNT-MASS.

Balance: AXIS BALANCE, POINT BALANCE EQUILIBRIUM.

Force: COMPULSION, BLOCKAGE, COUNTERFORCE, DIVERSION, ENABLEMENT, ATTRACTION, RESISTANCE.

Existence: CYCLE.

Attribute: HEAVY-LIGHT, DARK-BRIGHT, BIG-SMALL, WARM-COLD, STRONG-WEAK.

As Gibbs \& Colston (2006: 260) remark, image schemas "are a crucial, undervalued dimension of meaning". Furthermore, Cortés de los Ríos (2010: 88) argues that "image schemas are helpful in attaining the goal of persuading and influencing press readers' opinion". It is important to highlight that these cognitive structures 
carry axiological weight which is semantically relevant (Krzeszowski, 1990). Image schemas own a positive or negative value which is also added to the concept or picture and can therefore play a very important role in persuasion. Likewise, as argued by Krzeszowski (1993, 1997), this positive-negative axiological parameter offers special dynamism to the use of preconceived schemata in metaphorisation. Each pair of concepts follows a plus-minus parameter, which means that the first concept has a positive value and the second one, a negative value. However, we may find many instances in which there is an axiological clash, i.e. a so-called positive value is in fact negative, or vice versa. For example, let us consider the CONTAINER schema (IN-OUT). If we take our body as a container, whatever we put into it -food and air- we regard as positive because we need to eat and breathe in order to survive. However, we may find many instances in which there is an axiological clash, i.e. a so called positive value is in fact negative, or vice versa. If the container, for example is "home", this is positively charged (being IN positively charged) but if the container, is prison, this is negatively charged (being IN negatively charged") (Krzeszowski 1993: 317).

\section{Corpus and methodology}

The corpus for our analysis consists of a sample of ten covers of the weekly magazine The Economist published during the 2015-2017 period and collected from www.economist.com. Our selection of covers is justified on the following grounds:

(a) Covers are particularly good examples of interaction between the two modes, verbal and visual since both of them are dependent upon each other to convey the message.

(b) The covers included in our analysis depict different stages of Brexit and all combine suggestive pictures together with textual messages in order to communicate the development and impact of Brexit in Europe.

The selected covers will be presented in a chronological order, as an attempt to illustrate the different stages this historic event has undergone.

In order to clearly establish the presence of metaphoricity on our covers, we apply the procedure for metaphor identification (MIP) proposed by the Pragglejaz Group (2007). This method was used to recognise metaphorically used words, which involves the canonical case of metaphor identification in cognitive linguistics. The procedure consists of: (1) reading the whole text or transcript to understand what it is about; (2) deciding about the boundaries of words; (3) establishing the contextual meaning of the examined word; (4) determining the basic meaning of the word (most concrete, human-oriented and specific); (5) deciding whether the basic meaning of the word is sufficiently distinct from the contextual meaning; (6) deciding whether the contextual meaning of the word can be related to the more basic meaning by some form of similarity.

For the multimodal analysis of the covers selected we focus on Forceville $(1996,2009,2012)$ and Forceville \& Urios-Aparisi (2009), who provide clear instructions for the identification of cognitive devices in multimodal discourse. As a result, the following will be addressed: (i) identification of the monomodal or multimodal metaphors and metonymies on the covers, (ii) possible interactions between cognitive tools, and (iii) identification of image schemas on which metaphors and metonymies are based and whose purpose is to contribute to the creation of evaluative meaning. 
Regarding metaphor and metonymy, once we have identified them, we will determine whether they are monomodal (verbal or pictorial) or multimodal (pictorio-verbal, verbo-pictorial).

We will follow the selection made by Evans \& Green (2006) and Turner's (1991) motion image schema FORWARD-BACKWARD will be added to this list.

\section{Analysis of the covers}

A detailed analysis of the selected covers is outlined below.

4.1. Figure 1: May $2^{\text {nd }} 2015$

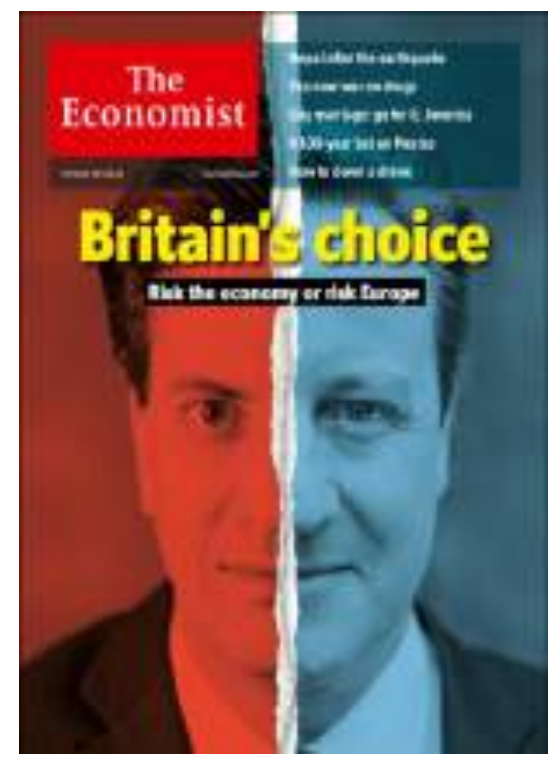

Figure 1. The Economist. May 2, 2015

The first cover (see Figure 1) was published on May $2^{\text {nd }}$ 2015. There was a general election on May 7th, 2015. The text refers to risking the economy by voting Labour or risking Europe by voting Conservative (as Cameron had promised a referendum on Europe). The face on the right is that of David Cameron, the then Prime Minister, the face on the left is Ed Miliband, the then Labour leader. We can see a pictorial metonymy here: CAMERON'S/MILIBAND'S FACE FOR BRITAIN (FACE FOR THE LEADER via A PART FOR THE WHOLE). The location of both politicians on the cover (left-right) is metonymically interpreted as LEADERS' LOCATION FOR IDEOLOGY, based on the spatial schema: LEFT-RIGHT. 
4.2. Figure 2: October $17^{\text {th }} 2015$

Figure 2. The Economist. October 17, 2015

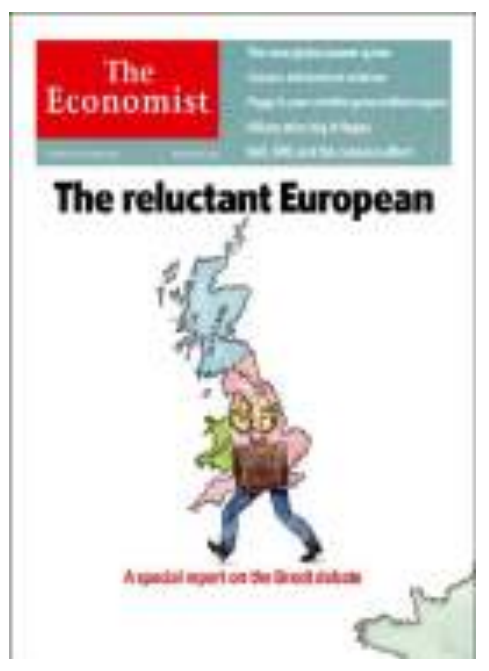

The second cover (see Figure 2) was published on October 17th 2015. It represents the desire of the UK to leave the EU. This visual element cues the pictorial metaphor Britain is an emigrant leaving Europe. This metaphor, which allows for the activation of personification, is based on the path schema providing the base for the journey metaphor. In addition, this pictorial metaphor interacts with the metonymy an emigrant leaving Europe for the unwilling intention to stay in Europe. This metonymy is supported by the verbal expression "The reluctant European" (effect for cause). Furthermore, the suitcase stands for the journey of the emigrant (Britain) to start a new life outside the EU (instrument for action). Finally, Britain is depicted metonymically as the map which symbolises the UK, the map for Britain (symbol for country).

4.3. Figure 3: February $27^{\text {th }} 2016$

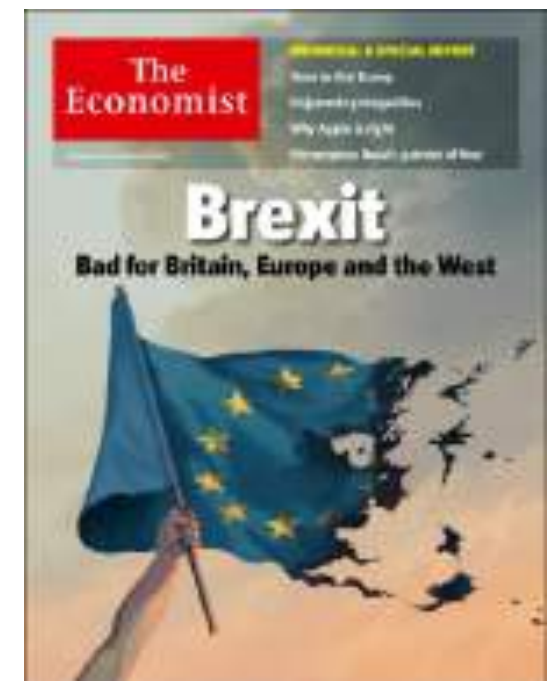

Figure 3. The Economist. February 27, 2016. 
The third cover (see Figure 3) was published on February $27^{\text {th }}$ 2016. It represents the tug-of-war between the UK and the EU since the desire for independence had grown. This cover portrays the verbo-pictorial metaphor BREXIT IS A FIERCE BATTLE and is based on the image schema of space (UP-DOWN). An axiological clash with the value of UP can be observed. Even though UP typically holds a positive value, here it is associated with a confrontation which is certainly negative. As depicted in the image, there is a human body part (an arm) representing the EU (via A PART FOR THE WHOLE). It is holding the EU flag (SYMBOL FOR COUNTRY) which is being burnt. Finally, Britain is depicted metonymically as the map which symbolises the UK. Through the silhouette of the map we can recognise the image of the UK that appears in the holes of the flag. This image suggests that the UK is coming out from the EU.

\subsection{Figure 4: June $18^{\text {th }} 2016$}

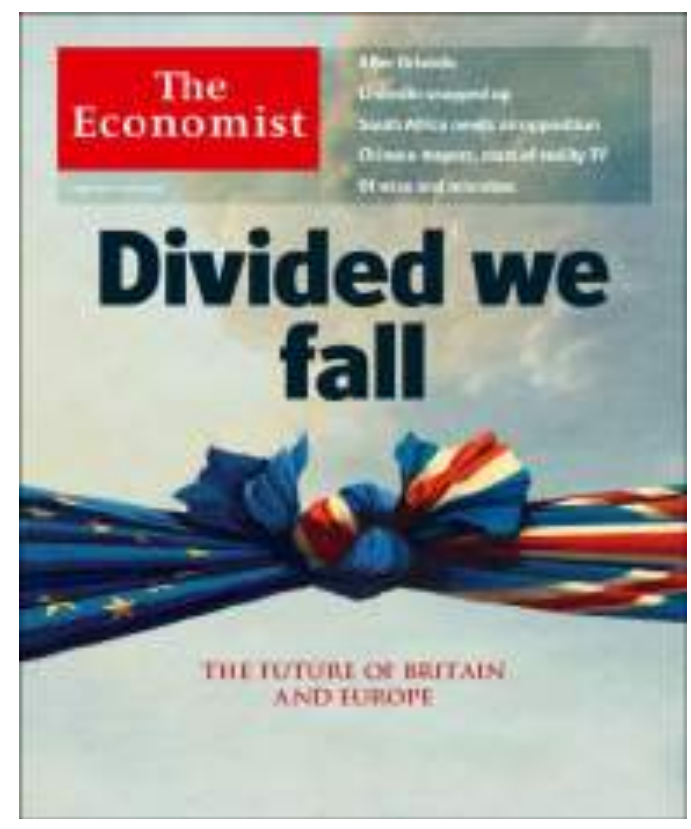

Figure 4. The Economist. June 18, 2016.

The fourth cover (see Figure 4) was published on June $18^{\text {th }}$ 2016, a week before the referendum took place in the UK. It represents the tense atmosphere within the country due to the upcoming referendum and its uncertain consequences. This atmosphere is also represented through the dark cloudy weather in the background. The two flags metonymically stand for their respective countries (SYMBOL FOR COUNTRY). The knot in the picture represents the marriage concept ("tie the knot") and could be formulated as a pictorial metaphor THE KNOT IS A MARRIAGE which is based on the metonymy THE KNOT FOR STRENGTH OF LOVE. This metaphtonymy relies on the FORCE (ATTRACTION-RESISTANCE) and EQUILIBRIUM image schemas. In addition, the MARRIAGE metaphor is reinforced by the verbal message "Divided we fall", which conveys a negative evaluation of the political situation and triggers the conceptual metaphor BAD IS DOWN. The division between the EU and the UK metonymically stands for the negative effects of not staying together in the future (EFFECT FOR CAUSE).

4.5. Figure 5: June $25^{\text {th }} 2016$ 
Figure 5. The Economist. June 25, 2016.

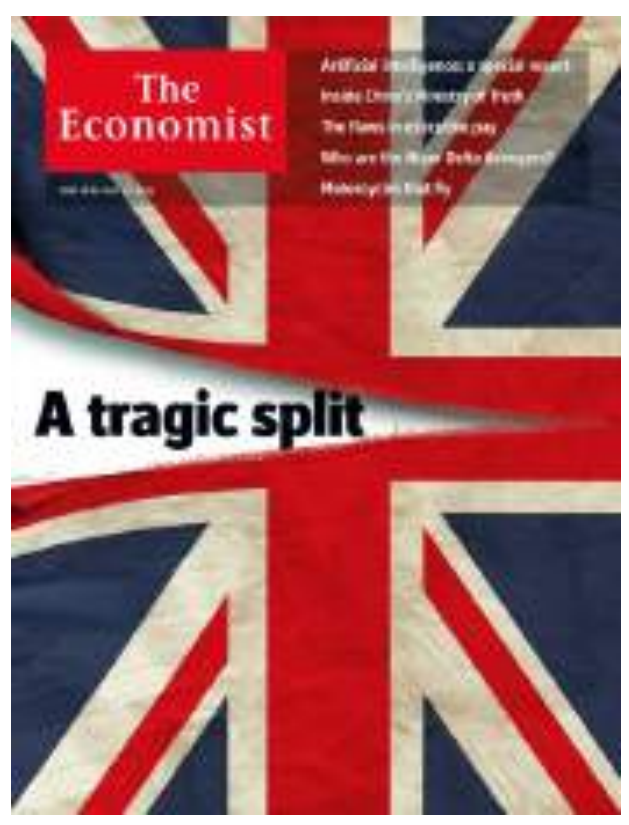

The fifth cover, (see Figure 5) which was published on June $25^{\text {th }} 2016$, two days after the referendum, showed that the UK citizens had voted to leave the EU. It represents the post-referendum feeling and the spreading sadness and uncertainty about what was about to happen. This cover triggers the verbo-pictorial metaphor THE CUT IS A TRAGIC SPLIT. The metaphor has a metonymic basis: the tragic split is shown metonymically from the distress caused by the political opinions within Britain (EFFECT FOR CAUSE). This metaphtonymy is supported by the interaction of the FORCE schema. The cut implies the use of force being negatively valued.

4.6. Figure 6: July $2^{\text {nd }} 2016$

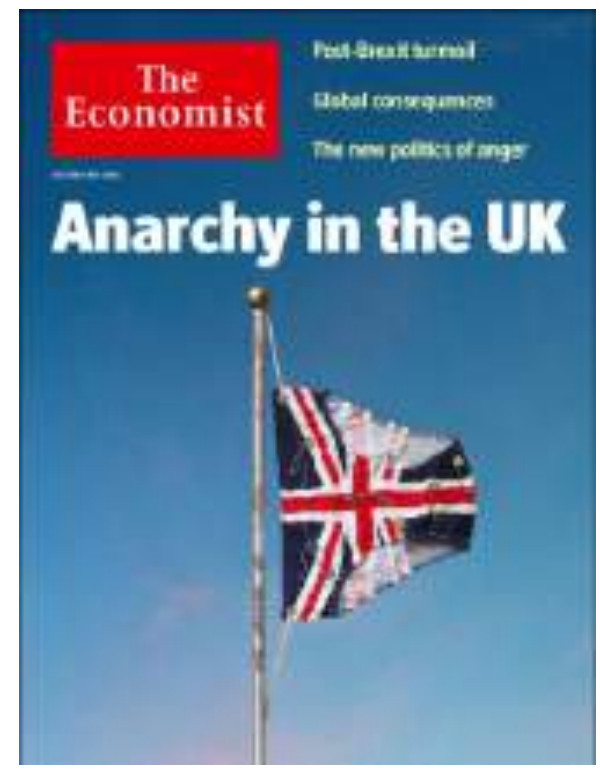

Figure 6. The Economist. July 2, 2016. 
The sixth cover (see Figure 6) was published on July 2nd 2016. It represents the post-Brexit political turmoil in the UK. The reader is presented with apparently non-related scenarios. The visual depiction of underpants hanging on a shabby flagpole metonymically represents the UK flag and the text stands for the bad political situation in the country. In addition, the verbal reference to a song by the British punk band Sex Pistols stands for a political ideology. The title of the song "Anarchy in the UK", released in 1976, is particularly pertinent in this case since in the song, various references are made to political groups around the world. The lyrics portray a particularly violent concept of anarchy that reflected the pervasive sense of economic frustration and social disenchantment. In fact, $60 \%$ of both men and woman in the UK aged between 50 and 64 years voted to leave the European Union. They belong to that generation that raised with the anarchist message of the Sex Pistols (O'toole, 2019). This cover reveals a case of a double multimodal metonymy: A PAIR OF UNDERPANTS ON A SHABBY FLAGPOLE FOR THE UK FLAG FOR A BAD POLITICAL SITUATION. In addition by virtue of a CAUSE FOR EFFECT metonymy the reader may infer that by splitting from the European Union, the UK can lose its prestigious position.

\subsection{Figure 7: October $8^{\text {th }} 2016$}

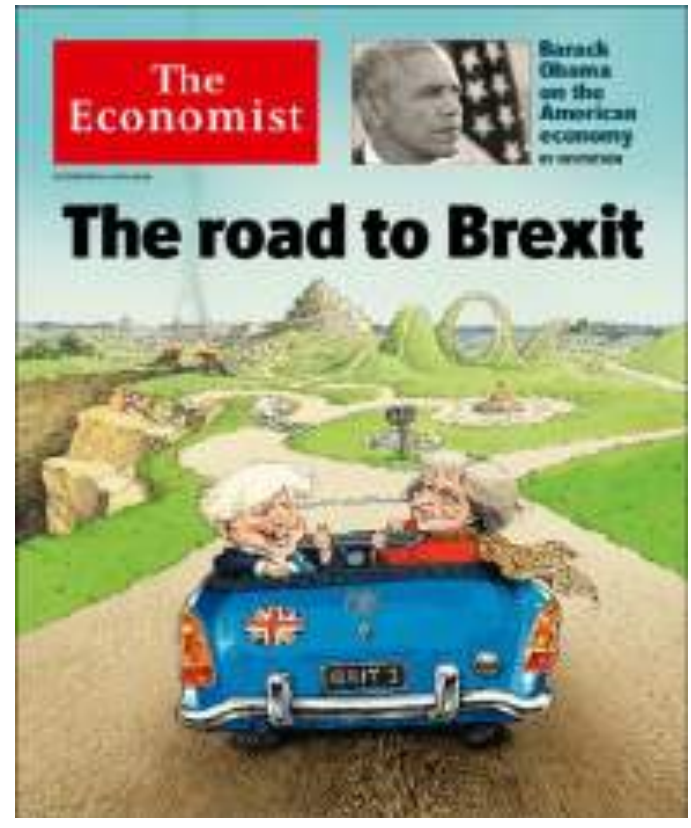

Figure 7. The Economist. October 8, 2016.

The seventh cover (see Figure 7) was published on October8 ${ }^{\text {th }}$ 2016. It represents the adversity of the post-Brexit consequences the UK is going through. This cover portrays the verbo-pictorial metaphor: BREXIT IS A TURBULENT ROAD which is based on the metonymy THE ROAD FOR BREXIT (which rests on THE PLACE FOR THE EVENT). This metaphor-metonymy combination is activated by the JOURNEY domain and is based on the interaction of image schemas: the schema of movement (FORWARD-BACKWARD) and spatial schema (STRAIGHTCURVED; LEFT-RIGHT). Within this JOURNEY scenario, it is logical to find elements that work as obstacles to reaching the destination. The crossroads in the picture depict a decision taken months ago, 'leave or stay'. The linear and easy road on the right-hand side can be comparable to a pleasant drive towards remaining a member of the EU. On the left-hand side, a turbulent, dangerously winding road symbolises the path towards leaving 
Europe and the troublesome negotiations ahead. In addition, within the JOURNEY domain Lakoff \& Johnson (1999) and Charteris-Black (2004) suggest the conceptual metaphor PURPOSEFUL ACTIVITY IS TRAVELLING TOWARDS A DESTINATION. The destination proposed by the then Prime Minister Theresa May and the then foreign secretary, Boris Johnson is to lead/drive the country towards the upcoming Brexit negotiations. As a result, we can activate a metonymy MAY AND JOHNSON FOR THE GOVERNMENT (LEADERS FOR INSTITUTION) which activates the conceptual metaphor NATIONS ARE PEOPLE. On the other hand, the car sticker stands for the UK flag (SYMBOL FOR COUNTRY). Finally, the number plate triggers the verbal metonymy BRIT 1 FOR BRITISH NATIONALISM, similar to the phrase used by President Trump in his electoral campaign: "America First".

\subsection{Figure 8: March $25^{\text {th }} 2017$}

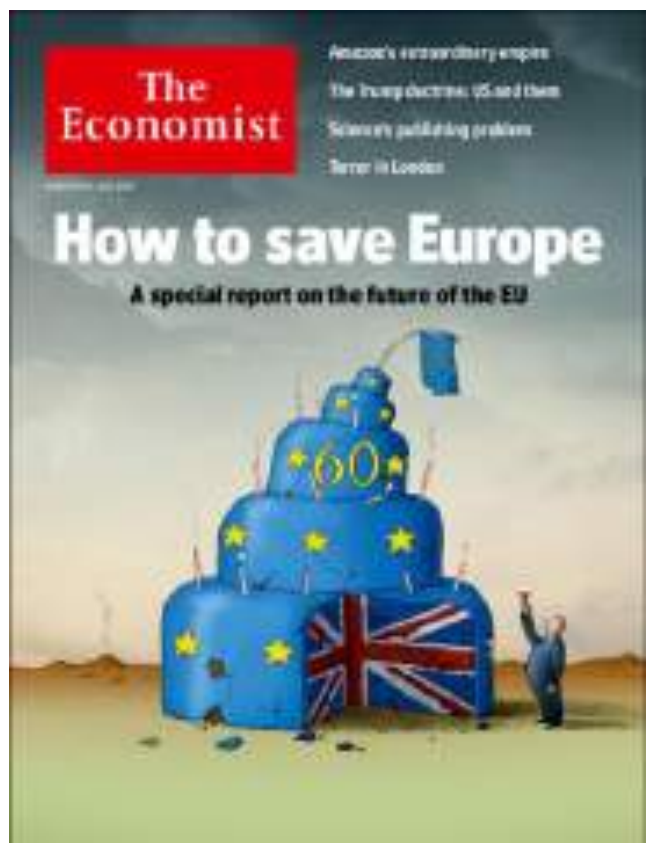

Figure 8. The Economist. March 25, 2017.

The eighth cover (see Figure 8) was published on March $25^{\text {th }} 2017$. It represents the European Union's $60^{\text {th }}$ anniversary which was on March $25^{\text {th }}$. On the one hand, this cover portrays two pictorial metonymies: THE BIRTHDAY CAKE FOR THE 60TH ANNIVERSARY OF THE EU and THE MISSING SLICE OF BIRTHDAY CAKE FOR A MISSING MEMBER OF THE EU (BRITAIN) (via A PART FOR THE WHOLE). The UK and the EU are depicted metonymically by means of both flags. Furthermore, the verbal reference "How to save Europe" is particularly pertinent in this case since one of the members of the EU is abandoning the institution. This text enables the reader to understand that the EU does not want to lose one of its members and renders the metaphor EUROPEAN INTEGRATION IS THE SEARCH FOR AN AGREEMENT BETWEEN THE EU AND THE UK. In addition, the ripped EU flag, placed on top of the cake with some torn pieces of the flag scattered on the floor, stands for the loss of the European integration (EFFECT FOR CAUSE). 


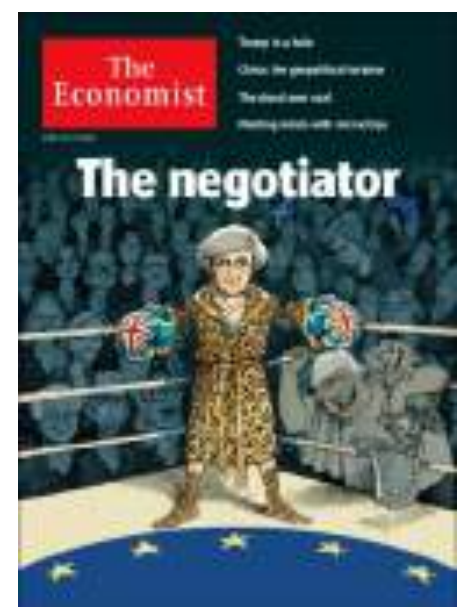

Figure 9. The Economist. April 1, 2017.

The ninth cover (see Figure 9 above) was published on April $1^{\text {st }} 2017$. It represents the formal beginning of the Brexit negotiations. This cover portrays the pictorial metaphor BREXIT IS A BOXING MATCH. This metaphor is activated by the SPORT domain which helps emphasise competitiveness. In addition, the image profiles the pictorio-verbal metaphor MAY IS A BOXER (THE NEGOTIATOR) AND JOHNSON IS HER COACH based on the attribute image schema (STRONG-WEAK), WEAK being valued negatively since Britain represented by May, has been pushed into the corner, as the EU occupies the better part of the ring to fight for its own interests. The image encodes the conceptual metaphor IMPORTANCE IS SIZE providing us with a powerful vision of the EU. In addition, May is pictured wearing gloves, a dressing gown and boots with animal print, standing for her fierce attitude in the battle. She stands for her country and its needs and her role is to fight for them in this pseudo political ring. This is an instance of a double pictorial metonymy CLOTHING STYLE FOR PEOPLE ATTITUDE FOR COUNTRY. Simultaneously, in the background of the image, we can see Europe's major political figures witnessing the Brexit negotiations and the two parties involved in Brexit, the UK and the EU, are also depicted metonymically by means of both flags.

4.10. Figure 10: July $22^{\text {nd }} 2017$

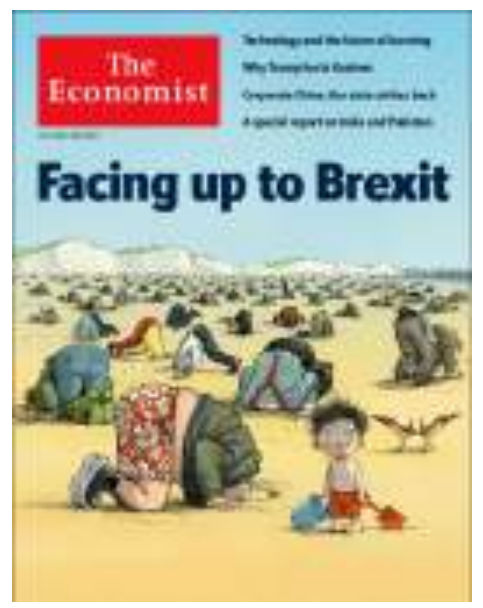

Figure 10. The Economist. July 22, 2017. 
The tenth cover (see Figure 10) which was published on July $22^{\text {nd }} 2017$ alludes to an English idiom: "to hide one's head in the sand" (to avoid, or try to avoid, a particular situation by pretending that it does not exist. The phrase refers to the belief that ostriches bury their heads in the sand when frightened, so as to avoid being seen (The Free Dictionary)). This picture represents how British citizens are facing their imminent departure from Europe. The image renders a situation which is negatively evaluated through the source domain of ANIMALS. This cover portrays a metaphtonymy. The pictorio-verbal metaphor: UK CITIZENS ARE OSTRICHES (PEOPLE ARE ANIMALS) interacts with the metonymy OSTRICHES FOR THEIR BEHAVIOUR (POSTURE FOR BEHAVIOUR) and is based on the space image schema (UP-DOWN) and containment (IN-OUT). "DOWN" and "IN" both hold negative axiological values. However, there is a clash in the image schema of containment "IN" since it typically depicts a positive value. UK citizens are portrayed with their faces buried under the sand because of the fear caused by Brexit. Here there is also a paradox with the verbal "Facing up to Brexit" and the pictorial elements (faces are buried which means avoidance and cowardice). As we can see this is good example of interaction between modalities. On the other hand, the boy image triggers the pictorial metonymy THE BOY FOR FUTURE OF BRITISH CITIZENS. Finally, the visual element cues a pictorial metonymy SAND FOR THE DESERT (NATURE FOR PLACE).

\section{Results}

The results of our analysis show that metaphors and metonymies are usually cued by pictures and also by the combination of pictures and text. It is also worth noting that we found more instances of pictorial metonymies in isolation than of pictorial metaphor working alone. We presume that this is probably due to the conceptually basic nature of metonymy as a reference point (Langacker, 1993). Furthermore, metonymy is an important cognitive device for passing meaning on to the reader and many metaphors are actually metonymy-based. Metaphtonymy appears in half of the covers studied (2, 4, 5, 7 and 10.) In our opinion, metaphtonymy appeals mostly to the emotional sphere while verbal metaphors appeal to reason.

The concept BREXIT can be profiled against different domains. Monomodal visual metaphors make reference to metaphorical scenarios. The analysis has showed that the meaning of Brexit is based on the JOURNEY metaphor, for example, the UK is likened to a person who has taken the decision to leave the place where he/she used to belong (the EU). Furthermore, the meaning of Brexit has been construed as a competitive and marital situation by means of the SPORT and MARRIAGE metaphors.

Meaning inferences are also produced through multimodal metaphor. The text either triggers or supports the metaphorical interpretation of the image. For example in figure 5 the image does not convey metaphorical meaning by itself; it is the text that profiles a metaphor THE CUT IS A TRAGIC SPLIT. In other words, the text simply acts as a linguistic support of a visual metaphor.

In our corpus, monomodal visual metonymies are very representative. The types of metonymy that can be observed on the sample covers are the following: A PART FOR THE WHOLE, LEADER FOR COUNTRY/INSTITUTION, INSTRUMENT FOR ACTION, EFFECT FOR CAUSE and CAUSE FOR EFFECT. The most recurrent metonymy is SYMBOL FOR COUNTRY. It is related to flag(s) and map(s) evoking either the UK or the EU.

The image schemas identified in our analysis have been mainly rendered pictorially and are those of movement (FORWARD-BACKWARD), path, space (UP-DOWN, LEFT-RIGHT, STRAIGHT-CURVED), attribute (STRONG-WEAK), force, equilibrium and containment (IN-OUT), space and force being the most recurrent image schemas. In some cases, the same image schema is used to convey different evaluative meanings. For example, the union between 
the UK and the EU is presented through the force and equilibrium schemas, both of them with a positive evaluation (see figure 4), while the cut regarded as a tragic split (see figure 5) is reinforced by the force schema being negatively evaluated. Finally, a negative evaluation in the communication of Brexit is sometimes conveyed through image schemas by means of some axiological clashes (see figures 3 and 10).

$\begin{array}{ll} & \begin{array}{l}\text { Metaphors and metonymies are usually cued by } \\ \text { pictures in isolation and by the interaction of text } \\ \text { and pictures. }\end{array} \\ \text { The corpus reveals a clear preference for mono- } \\ \text { modal metonymies of pictorial type. } \\ \text { According to multimodality verbo-pictorial meta- } \\ \text { phors are the most recurrent. }\end{array}$

Table 1. Cognitive tools and modalities reflected in our corpus

\section{Conclusions}

The present paper has attempted to show how verbal, pictorial and multimodal modes contribute to the communication of the separation process between Britain and the EU, known as Brexit, by means of cognitive tools during the 2015-2017 period. Journalists exploit metaphor, metonymy and image schemas in the verbal and/or visual mode to create powerful messages and thus call readers' attention. Our analysis shows cognitive tools are more prevalent in the visual than the verbal mode. This indicates how important pictorial metonymies and image schemas have become to the communication of Brexit process. According to multimodality, metaphors of verbo-pictorial type are the most recurrent. In this regard, Forceville (2008) claims that multimodal metaphors have a more direct and emotive impact on the reader than purely verbal metaphors. It is interesting to highlight the persuasive power which monomodal and multimodal cognitive tools have due to their ability to influence readers and transmit messages. In short, all these tools help the journalist to show reality in a certain way and to shape our thoughts, behavior, and reactions. The study of the diverse set of conceptual mechanisms involved in the conceptualization of Brexit makes it easy to understand the complexity of this political phenomenon. The scope of the paper being limited, further research should be carried out on a wider corpus to provide further evidence of the findings. 


\title{
Declaration of conflicting interests
}

The author(s) declared no potential conflicts of interest with respect to the research, authorship, and/or publication of this article.

\section{Funding}

The author(s) received no financial support for the research, authorship, and/or publication of this article.

\begin{abstract}
About the authors
$\mathrm{M}^{\mathrm{a}}$ Enriqueta Cortés de los Ríos is a lecturer in the Department of Philology at the University of Almería (Spain). She has been dealing with Languages for Specific Purposes for the whole of her career, especially in the field of Economic and Business English. Her main areas of research interest are cognitive semantics, axiological linguistics, English for Specific Purposes (ESP) and didactics applied to languages for specific purposes. She has participated in international and national conferences. She has published several journal articles, book chapters and books.

Tamara Hernández Aparicio graduated in English Studies from the University of Granada (Spain) and she completed postgraduate studies at the University of Almeria in English Studies, Professional Applications and Intercultural Communication. Her main research interests focus on professional language and English for Specific Purposes.
\end{abstract}

\section{Acknowledgements}

Mention to image copyrights:

The use of images /covers in this paper is for educational purposes, it is neither commercial, nor lucrative. The authorship of the images corresponds to:
(a) Mirropix (Figure 1: May $2^{\text {nd }} 2015$ )
(b) Jon Berkeley (Figure 2: October 17th 2015)
(c) David Parkins (Figure 3: February $27^{\text {th }}$ 2016)
(d) David Parkins (Figure 4: June $18^{\text {th }}$ 2016)
(e) Derek Bacon (Figure 5: June $25^{\text {th }}$ 2016)
(f) The Economist (Figure 6: July $2^{\text {nd }}$ 2016)
(g) David Parkins (Figure 7: October $8^{\text {th }}$ 2016)
(h) Jon Berkeley (Figure 8: March $25^{\text {th }}$ 2017)
(i) David Parkins (Figure 9: April $1^{\text {st }}$ 2017)
(j) David Parkins (Figure 10: July 22 ${ }^{\text {nd }}$ 2017) 


\section{References}

Barcelona, A. (Ed.) (2000). Metaphor and metonymy at the crossroads: A cognitive perspective. Berlin: Mouton de Gruyter.

Bijeikienė, V., \& Meškauskienè, A. (2013). Metaphor and metonymy in English for politics (ESP) course: Students' representations and practices. Sustainable Multilingualism, 2, 90-99.

Burkholder, T. R., \& Henry, D. (2009). Criticism of metaphor. In J. A. Kuypers (Ed.), Rhetorical criticism: Perspectives in action (pp. 97-114). Lanham, MD: Lexington Books.

Caballero, R., \& Suárez-Toste, E. (2008). Translating the senses. Teaching the metaphors in wine speak. In F. Boers, \& S. Lindstromberg (Eds.), Cognitive linguistic approaches to teaching vocabulary and phraseology (pp. 241-259). Berlin: Mouton de Gruyter.

Cammaerts, B. (2012). The strategic use of metaphors by political and media elites: The 2007-11 Belgian constitutional crisis. International Journal of Media \& Cultural Politics, 8(2/3), 229- 249.

Charteris-Black, J. (2004). Corpus approaches to critical metaphor analysis. Basingstoke/New York: Palgrave Macmillan.

Charteris-Black, J., \& Musolff, A. (2003). Battered 'hero' or 'innocent victim'? A comparative study of metaphors for euro trading in British and German financial reporting. English for Specific Purposes, 22, 153-176.

Chilton, P (2008). Political terminology. In R. Wodak, \& V. Köller (Eds.), Handbook of communication in the public sphere (pp. 225242). Berlin/NewYork: Mouton de Gruyter.

Chilton, P. \& Schäffner, C. (1997). Discourse and Politics. In T. A. van Dijk (Ed.), Discourse as social interaction (pp.206.230). London: Sage.

Cortés de los Ríos, M. E. (2010). Cognitive devices to communicate the economic crisis: An analysis through covers in The Economist. Ibérica, 20, 81-106.

Cortés de los Ríos, M. E. \& Felices Lago, A. (2017). A cognitive-axiological approach to the chairman's letter of the leading civil aircraft manufacturers. Ibérica, 34, 111-136.

Deepali, R. (2016). Impact and Relevance of Design Principles in Magazine Covers: A Content Analysis. Amity Journal of Media \& Communication Studies, 6(1), 15-25.

Díez Velasco, O. I. (2001). Metaphor, metonymy, and image-schemas: An analysis of conceptual interaction patterns. Journal of English Studies, 3, 47-63.

Đurović, T., \& Silaški, N. (2018). The end of a long and fraught marriage: Metaphorical images structuring the Brexit discourse. Metaphor and the Social World, 8(1), 25-39.

Evans, V., \& Green, M. (2006). Cognitive linguistics: An introduction. Mahwah NJ: Lawrence Erlbaum Associates.

Forceville, C. (1996). Pictorial metaphor in advertising. London: Routledge.

Forceville, C. (2006). Non-verbal and multimodal metaphor in a cognitivist framework: Agendas for research. In G. Kristiansen, M. Achard, R. Dirven, \& F. Ruiz de Mendoza Ibáñez (Eds.), Cognitive linguistics: Current applications and future perspectives (pp. 379-402). Berlin: Mouton de Gruyter.

Forceville, C. (2008). Metaphor in pictures and multimodal representations. In R. W. Gibbs Jr. (Ed.), The Cambridge handbook of metaphor and thought (pp. 462-482). Cambridge: Cambridge University Press.

Forceville, C. (2009). Non-verbal and multimodal metaphor in a cognitivist framework: Agendas for research. In C. J. Forceville, \& E. Urios-Aparisi (Eds.), Multimodal metaphor (pp. 19-42). Berlin/NewYork: Mouton de Gruyter.

Forceville, C. (2012). Creativity in pictorial and multimodal advertising metaphors. In R. Jones (Ed.), Discourse and creativity (pp. 113-132). Harlow: Pearson/Longman.

Forceville, C. (2016). Visual and multimodal metaphor in film: Charting the field. In K. Fahlenbrach (Ed.), Embodied metaphors in film, television and video games: Cognitive approaches (pp. 17-32). London: Routledge.

Forceville, C., \& Urios-Aparisi, E. (2009). Multimodal metaphor. Berlin: Mouton de Gruyter.

García Castillo, J.F. (2004). Metonymy and thought: verifying Ruíz de Mendoza \& Otal's model of metonymy (a corpus-driven research). Jornades de Foment de la Investigació, 1-14. http://repositori.uji.es/xmlui/bitstream/handle/10234/78888/forum 2004 
3.pdf?sequence $=1$ [12-102019].

Gibbs, R., \& Coslton, H. (2006). The cognitive psychological reality of image schemas and their transformations. In D. Geraerts (Ed.), Cognitive linguistics (pp. 239-268). Berlin: Mouton de Gruyter.

Goossens, L. (1995). Metaphtonymy: The interaction of metaphor and metonymy in expressions for linguistic action. In L. Goossens, P. Pauwels, B. Rudzka-Ostyn, A. M. Simon-Vanderbergen, \& J. Vanparys (Eds.), By word of mouth: Metaphor, metonymy and linguistic action in a cognitive perspective (pp. 159-174). Amsterdam: John Benjamins.

Johnson, M. (1987). The body in the mind: The bodily basis of meaning, imagination, and reason. Chicago: The University of Chicago Press.

Koller, V., Kopf, S., \& Miglbauer, M. (Eds.) (2019). Talking about Brexit-voices from before and after the referendum. London and New York: Routledge.

Kövecses, Z. (2010). Metaphor. Oxford/New York: Oxford University Press.

Kress, G., \& van Leeuwen, T. (2001). Multimodal discourse: The modes and media of contemporary communication. London: Arnold.

Kress, G., \& Van Leeuwen, T. (2006). Reading Images (2nd ed.). London: Routledge.

Krzeszowski, T. P. (1990). The axiological aspect of idealized cognitive models. In J. Tomaszczyk, \& B. Lewandowska (Eds.), Meaning and lexicography (pp. 135-165). Amsterdam: John Benjamins.

Krzeszowski, T. P. (1993). The axiological parameter in preconceptual image schemata. In R. A. Geiger, \& B. Rudzka-Ostyn (Eds.), Conceptualizations and mental processing in language (pp. 307-330). Berlin: Mouton de Gruyter.

Krzeszowski, T. P. (1997). Angels and devils in hell. Elements of axiology in semantics. Warsaw: Energeia.

Lakoff, G. (1987). Women, fire, and dangerous things: What categories reveal about the mind. Chicago: University of Chicago Press.

Lakoff, G. (1993). The contemporary theory of metaphor. In A. Ortony (Ed.), Metaphor and thought (2nd ed.) (pp. 202-251). Cambridge: Cambridge University Press.

Lakoff, G., \& Johnson, M. (1980). Metaphors we live by. Chicago: University of Chicago.

Lakoff, G., \& Johnson, M. (1999). Philosophy in the flesh. The embodied mind and its challenge to western thought. New York: Basic Books.

Lakoff, G., \& Turner, M. (1989). More than cool reason: A field guide to poetic metaphor. Chicago: University of Chicago Press.

Langacker, R. (1993). Reference-point constructions. Cognitive Linguistics, 4, 1-38.

Mio, J. S. (1997). Metaphor and politics. Metaphor and Symbol, 12(2), 113-133.

Musolff, A. (2017). Truth, lies and figurative scenarios: Metaphors at the heart of Brexit.

Journal of Language and Politics, 16(5), 641-657.

Negro Alousque, I. (2015). CORRUPTION IS DIRT: Metaphors for political corruption in the Spanish press. Bulletin of Hispanic Studies, 92(3), 231-238.

O'toole, F. (2019). Heroic Failure: Brexit and the Politics of Pain. Head of Zeus: London.

Pérez Sobrino, P. (2017). Multimodal metaphor and metonymy in advertising. Amsterdam/Philadelphia: John Benjamins.

Pragglejaz Group (2007). MIP: A method for identifying metaphorically used words in discourse. Metaphor and Symbol, 22(1), 1-39.

Ruiz de Mendoza Ibáñez, F. J. (1997). Metaphor, metonymy and conceptual interaction. Atlantis, XIX(1), 281-295.

Ruiz de Mendoza Ibáñez, F. J. (2000). The role of mappings in understanding metonymy. In A. Barcelona (Ed.), Metaphor and metonymy at the crossroads: A cognitive perspective (pp. 109-132). Berlin: Mouton de Gruyter.

Ruiz de Mendoza Ibáñez, F. J. \&Díez Velasco, O. I. (2002). Patterns of conceptual interaction. In R. Dirven, \& R. Pörings (Eds.), Metaphor and metonymy in comparison and contrast (pp. 489-532). Berlin: Mouton de Gruyter.

Ruiz de Mendoza Ibáñez, F. J., \& Pérez-Hernández, L. (2011). The contemporary theory of metaphor: Myths, developments and challenges. Metaphor and Symbol, 26(3), 161-185. 
Ruiz de Mendoza Ibáñez, F. J., \& Galera Masegosa, A. (2014). Cognitive modeling: A linguistic perspective. Amsterdam/Philadelphia: John Benjamins.

Silaški, N., \& Đurović, T. (2010). The conceptualisation of the global financial crisis via the ECONOMY IS A PERSON metaphor - A contrastive study of English and Serbian. Facta Universitatis, Series: Linguistics and Literature, 8(2), 129-139.

Silaški, N., \& Đurović, T. (2017). Saving the euro: A multimodal analysis of metaphors depicting the Eurozone crisis. Ibérica, 33, 125146.

Turner, M. (1991). Reading minds: The study of English in the age of cognitive science. Princeton, NJ: Princeton University Press.

Ventola, E., Cassily, C., \& Kaltenbacher, M. (2004). Perspectives on multimodality. Amsterdam: John Benjamins. 